\title{
EFFECT OF AMINO ACIDS ON RAM SPERM FREEZABILITY, BIOCHEMICAL ULTRASTRUCTURE CHANGES AND FERTILIZING POTENTIALS
}

\author{
BADR, M.R.; RAWASH, Z.M.; GHADA, H. ABD EL RAHMAN; ASSI, M.M. and HASAN, H.M. \\ Artificial Insemination and Embryo Transfer Department, Animal Reproduction Research Institute, Al Haram, P. O. 12556, \\ Giza, Egypt.
}

Email: magdybadr69@yahoo.com

Assiut University web-site: www.aun.edu.eg

\section{ABSTRACT}

Received at: 23/6/2015

Accepted: 30/7/2015
The objective of this study was to investigate the effects of non essential amino acids solution (NESS) to freezing extender on standard qualitative semen parameters (motility, viability and acrosomal integrity), oxidative parameters (antioxidant enzymes activities and lipid peroxidation), ultrastructure alterations and in vitro fertilizing potentials of frozen-thawed ram semen. Ejaculate samples were collected with artificial vagina from five adult fertile rams and diluted with Tris-base extender containing non essential amino acids solution $(20,50,100$ and $200 \mu \mathrm{l} / \mathrm{ml})$ or without amino acids (control). Diluted semen was cooled to $4^{\circ} \mathrm{C}$ throughout one hour and frozen in $0.25 \mathrm{ml}$ straws, prior to being stored in liquid nitrogen. Cryopresreved spermatozoa were assessed for post-thawing sperm motility, viability and acrosomal integrity, ultrastructure changes, antioxidant activities, lipid peroxidation and in vitro fertilizing potentials. The current results clearly indicated that adding $100 \mu 1 / \mathrm{ml}$ non essential amino acids to Tris extender significantly improved $(\mathrm{P}<0.05)$ postthawing motility, viability index and maintained acrosomal integrity $(65.00 \pm 2.89 \%$, $169.16 \pm 5.46$ and $12.67 \pm 1.2 \%$, respectively) compared with the control semen $(50.00 \pm 7.16 \%, 109.33 \pm 8.37$ and $21.66 \pm 3.38 \%)$. Moreover, addition of $100 \mu 1 / \mathrm{ml}$ non essential amino acids to the semen extender significantly diminished $(\mathrm{P}<0.05)$ the lipid peroxidation $(11.91 \pm 1.76 \mathrm{nmol} / \mathrm{ml})$ compared with the control semen $(20.11 \pm 2.68 \mathrm{nmol} / \mathrm{ml})$. Furthermore, the current results illustrated that addition of $100 \mu \mathrm{l} / \mathrm{ml}$ non essential amino acids protected the plasma membrane, acrosomal region and mitochondria and maintained the ultrastructure integrity of the cryopresreved spermatozoa and DNA integrity compared with the control spermatozoa. All of these previously enhanced semen characteristics were reflected positively on its in vitro fertilizing capacity. Therefore, the present results revealed that addition of $100 \mu \mathrm{l} / \mathrm{ml}$ non essential amino acids to the freezing extender might improve semen quality and reduce cryodamage of the ram spermatozoa.

Key words: Amino acids, Ram, Sperm, Ultrastructure.

\section{INTRODUCTION}

Semen cryopreservation is one of the most effective and acceptable methods to maintain ram fertility potential. Unfortunately, cryopreservation generates sublethal injury to the sperm due to chemical, osmotic, thermal, and mechanical stresses, which may deteriorate the fertility of ram semen probably by affecting the sperm motility, viability, plasma membrane, acrosomal and DNA integrity (Peris et al., 2007, Maia et al., 2009 and Sicherlea et al., 2011).

Cryopreservation of mammalian semen increased the levels of reactive oxygen species molecules that caused lipid peroxidation of the bio-membrane system by reducing the antioxidant potential of the cryopresreved semen (Aitken, 2000). The cause of oxidative stress is considered as a major conducive factor to male infertility and decreased semen quality during the preservation process (Betteridge, 2000). All cellular components (e.g. nucleic acids, lipids and sugars) are possible targets of oxidative stress; moreover, the consequence of excessive ROS production leads to lipid peroxidation, decreased motility, viability and increased mid-piece sperm morphological defects (Budai et al., 2014). Ram sperm cells are vulnerable to free radical attack, since are rich in polyunsaturated fatty acids (PUFA), therefore ROS can combine readily with them, directly causing lipid peroxidation (LPO). Lipid 
peroxidation chain reaction has a harmful effect on both the movement and the physical attribution of the membrane surface structure of the sperm cells that may lead to diminish membrane fluidity. These fundamental membrane changes in the spermatozoa deprive the competence of these cells for fertilizing the egg (Esmaeili et al., 2012). Therefore, in recent years, different antioxidants have been used to protect spermatozoa from the deleterious effects of cryopreservation and free radicals (Uysal and Bucak 2007, Giulini et al., 2009 and Camara et al., 2011).

Since the discovery of the biological effects of amino acids in prevention of cell damage during freezing stress (Chu et al., 1974), numerous studies investigated their protective effects on different type of animal cells against freezing damage including sperm (Atessahin et al., 2008 and El- Sheshtawy et al., 2008). The published reports suggested that addition of amino acids to extender have important roles in preventing cryogenic damage and improving postthawing sperm motility, viability, acrosome integrity and membrane integrity in goat, bovine, buffalo, and ram's spermatozoa during the frozen stage (Uysal and Bucak, 2007 and Ali Al Ahmad et al., 2008).

However, the exact mechanism by which these amino acid components protect spermatozoa during freezingthawing process, have not clearly understood and are still unclear. Therefore, the main goal of this study was to study the effect and optimal concentrations of non essential amino acids on freezability of ram spermatozoa.

\section{MATERIALS and METHODS}

\section{Chemicals}

The MEM non essential amino acids solution (M 7146) used in that study were obtained from SigmaAldrich.

\section{Extender preparation}

The cryoprotective extender used in this study was Tris-based extender (375mM Tris; $124 \mathrm{mM}$ citric acid; $41.6 \mathrm{mM}$ glucose, $20 \%(\mathrm{v} / \mathrm{v})$ egg yolk , 5\% $(\mathrm{v} / \mathrm{v})$ glycerol , $\mathrm{pH}=6.8$ ) supplemented with different concentrations of non essential amino acids.

\section{Semen Collection}

Semen samples were collected from five fertile rams (aged 2 to 3 y), kept at the Animal Reproduction Research Institute farm (Cairo, Egypt). Two consecutive ejaculates were collected from each ram weekly for successive six weeks using an artificial vagina. The ejaculates were pooled to eliminate variability between the collected samples. The semen samples were assessed for volume, sperm concentration, and percentage of motile spermatozoa. The ejaculates with at least $70 \%$ motility and $>85 \%$ normal sperm morphology were used for the present study. All experiments were done with at least 3 replicates for each group.

\section{Semen processing}

After evaluation, the fresh semen samples were pooled and then split into 5 equal portions and diluted at $30^{\circ} \mathrm{C}$ with Tris-based extender supplemented with different concentrations of non essential amino acids (20, 50, 100 and $200 \mu \mathrm{l} / \mathrm{ml})$ vs Tris-based extender only (control) to obtain to a final concentration of approximately $4 \times 10^{8}$ sperm cells $/ \mathrm{ml}$. The fresh semen samples were transferred to pre warmed tubes. Semen was cooled from 37 to $5^{\circ} \mathrm{C}$ throughout $60 \mathrm{~min}$ in a cold cabinet. The cooled semen was loaded into $0.25 \mathrm{ml}$ polyvinyl chloride straws (IMV, L'Aigle, France), horizontally placed in a refrigerator and kept at $4^{\circ} \mathrm{C}$ for $1 \mathrm{~h}$. These straws were then placed $8 \mathrm{~cm}$ above the liquid nitrogen surface where the temperature was approximately $-120^{\circ} \mathrm{C}$. After $15 \mathrm{~min}$, they were immersed directly into liquid nitrogen $\left(-196^{\circ} \mathrm{C}\right)$ for storage. The straws were stored at least for 24 hour before evaluation. Frozen semen straws were thawed in water bath at $37^{\circ} \mathrm{C}$ for 30 sec. Post-thawing sperm motility; viability and acrosomal integrity were assessed according to Salamon and Maxwell (2000).

\section{Ultrastructure analysis of the cryopresreved spermatozoa}

The ultrastructure changes occurred for the cryopresreved ram spermatozoa were evaluated by transmission electron microscopy (TEM). Straws from each treatment were washed three times by centrifugation at $1000 \mathrm{rpm}$ for $5 \mathrm{~min}$ using phosphate buffer Saline (PBS). The frozen-thawed semen was prefixed for 2-3 h with PBS containing $2 \%$ glutaraldehyde, washed three times by centrifugation at $1000 \mathrm{rpm}$ with PBS ( $\mathrm{pH} 7.4)$ for 5 min at $4^{\circ} \mathrm{C}$ and post-fixed in $1 \%$ osmium tetroxide for $1-2 \mathrm{~h}$ at $4^{\circ} \mathrm{C}$ (Boonkusol, 2010). Spermatozoa were dehydrated in propylene oxide and embedded in epon resin. Ultrathin sections were cut using the Leica EM UC6 ultra microtome and stained with uranylacetate and lead citrate. Randomly fields were examined by a transmission electronic microscope (JEOL-EM-100 S at TEM lab FA-CURP, Faculty of Agriculture, Cairo University -Research Park CURP). Images were captured by CCD camera model AMT, optronics camera with 1632 x 1632 pixel formate as side mount configuration.

\section{Assessment of sperm DNA integrity}

DNA integrity and the incidence of DNA strand breaks or fragmentation was detected using the alkaline single cell gel electrophoresis (comet) assay according to Boe-Hansen (2005). Briefly, frozenthawed spermatozoa were diluted in PBS, embedded in agarose, followed by cell lysis, DNA decondensation, electrophoresis and DNA staining with ethidium bromide. The cells were then 
visualized by fluorescent microscopy. Intact nuclei appeared to have compact and brightly fluorescent heads; in contrast, strand breaks in damaged cells allow DNA migration during electrophoresis, and a tail of DNA could be seen behind the head, giving the appearance of a comet (Hughes et al., 1996). After subjecting the spermatozoa to the comet assay, sperm nuclei were analyzed by computer soft ware program (Komet IV).

\section{Biochemical Assays \\ Superoxide Dismutase (SOD)}

The SOD activity of frozen-thawed spermatozoa was measured at $560 \mathrm{~nm}$ on a spectrophotometer and expressed as units per milliliter according to Flohe and Otting (1984).

\section{Glutathione Reductase (GSH)}

The GSH content of frozen-thawed spermatozoa was measured at $412 \mathrm{~nm}$ on a spectrophotometer and the values of GSH were expressed as units using the method of Sedlak and Lindsay (1968).

\section{Lipid Peroxidation (LPO)}

The concentrations of Malondialdehyde (MDA), as indices of the LPO in the sperm samples, were measured using the thiobarbituric acid reaction according to the method of Placer et al. (1966). The MDA concentrations were expressed in nmol/10 ${ }^{9}$.

\section{Total Antioxidant Capacity (TAC)}

The TAC content of frozen-thawed spermatozoa was measured at $532 \mathrm{~nm}$ on a spectrophotometer and the values of TAC were expressed as $\mathrm{m} \mu / \mathrm{ml}$ according to Cortassa et al. (2004).

\section{Evaluation of in vitro fertilizing potential of the treated buffalo semen:}

Three straws from each treatment were thawed in a water bath at $37^{\circ} \mathrm{C}$ for $30 \mathrm{sec}$. The most motile spermatozoa were separated by swim up technique in the fertilization medium, modified Tyrode's Albumin-Lactate-Pyruvate (TALP) containing 6 $\mathrm{mg} / \mathrm{ml}$ bovine serum albumin (BSA), for 1 hour. The uppermost layer of the medium containing the most spermatozoa was washed twice by centrifugation at $1800 \mathrm{rpm}$ for 10 minutes. The sperm pellet was resuspended in the fertilization TALP medium containing $10 \mu \mathrm{g} / \mathrm{ml}$ heparin (Parrish et al., 1988). After appropriate dilution, $2 \mu \mathrm{l}$ of sperm suspension was added to the fertilization drops, containing the matured oocytes, at a final concentration $2 \times 10^{6}$ sperm cell $/ \mathrm{ml}$. Gametes were co-incubated in the fertilization drops under sterile mineral oil for 6 hour at $39^{\circ} \mathrm{C}$ in an atmosphere of $5 \% \mathrm{CO}_{2}$ in air with maximum humidity. At the end of gametes coincubation, some inseminated oocytes were examined for signs of fertilization by aceto-orcein staining according to Leoni et al. (2006).

\section{Statistical analysis}

All data were analyzed by using Costat Computer Program (1986), Version 3.03 copyright Cottort Software, and were compared by the least significant difference least (LSD) at 5\% levels of probability. The results were expressed as means \pm SE. The mean values of the percentages of motile sperm, acrosomeintact sperm, enzyme activity and embryo development were compared using Duncan's multiple range test by one-way ANOVA procedure, when the F-value was significant $(P<0.05)$. Sperm fertilizing capacity were assessed using Chi-square $\left(X^{2}\right)$ analysis.

\section{RESULTS}

The results presented in table 1 revealed that, addition of $100 \mu \mathrm{l} / \mathrm{ml}$ non essential amino acids to the freezing extender improved the freezability of ram spermatozoa compared with the control semen. Addition of $100 \mu \mathrm{l} / \mathrm{ml}$ non essential amino acids significantly $(\mathrm{P}<0.05) \quad$ improved post-thawing sperm motility; viability index and maintained acrosomal integrity $(65.00 \pm 2.89 \%, 169.16 \pm 5.46$ and $12.67 \pm 1.20 \%$, respectively) compared with the control semen $(50.00 \pm 7.16 \%, 109.33 \pm 8.37$ and $21.66 \pm 3.38 \%$, respectively). However, $200 \mu \mathrm{l} / \mathrm{ml}$ non essential amino acids drastically $(\mathrm{P}<0.05)$ reduced post-thawing sperm motility; viability index and deteriorated the acrosomal integrity $(33.33 \pm 4.04 \%, 94.33 \pm 7.54$ and $24.67 \pm 2.02 \%$, respectively).

Table 1: Effect of non essential amino acids addition to semen extender on ram semen freezability

\begin{tabular}{lllll}
\hline $\begin{array}{c}\text { Different } \\
\text { treatments }\end{array}$ & $\begin{array}{c}\text { motility after1 } \\
\text { hour dilution } \\
(\%)\end{array}$ & $\begin{array}{c}\text { Post-thawing } \\
\text { motility } \\
(\%)\end{array}$ & Viability index & $\begin{array}{c}\text { Acrosomal abnormality } \\
(\%)\end{array}$ \\
\hline Control & $75.00 \pm 2.89^{\mathrm{a}}$ & $50.00 \pm 7.16^{\mathrm{bc}}$ & $109.33 \pm 8.37^{\mathrm{cd}}$ & $21.66 \pm 3.38^{\mathrm{ab}}$ \\
\hline $\mathrm{NESS} 20 \mu \mathrm{l} / \mathrm{ml}$ & $78.33 \pm 4.42^{\mathrm{a}}$ & $51.66 \pm 4.04^{\mathrm{b}}$ & $127.66 \pm 10.19^{\mathrm{bc}}$ & $17.33 \pm 2.6^{\mathrm{abc}}$ \\
\hline $\mathrm{NESS} 50 \mu \mathrm{l} / \mathrm{ml}$ & $76.67 \pm 1.67^{\mathrm{a}}$ & $55.00 \pm 5.00^{\mathrm{ab}}$ & $142.5 \pm 10.79^{\mathrm{ab}}$ & $15.33 \pm 1.76^{\mathrm{bc}}$ \\
\hline $\mathrm{NESS} 100 \mu \mathrm{l} / \mathrm{ml}$ & $80.00 \pm 2.89^{\mathrm{a}}$ & $65.00 \pm 2.89^{\mathrm{a}}$ & $169.16 \pm 5.46^{\mathrm{a}}$ & $12.67 \pm 1.2^{\mathrm{c}}$ \\
\hline $\mathrm{NESS} 200 \mu \mathrm{l} / \mathrm{ml}$ & $76.66 \pm 4.41^{\mathrm{a}}$ & $33.33 \pm 4.04^{\mathrm{c}}$ & $94.33 \pm 7.54^{\mathrm{d}}$ & $24.67 \pm 2.02^{\mathrm{a}}$ \\
\hline
\end{tabular}

Values with different superscript letters in the same columns are significantly different at least $(\mathrm{P}<0.05)$.

NESS: non essential amino acids 
Data regarding the effect of non essential amino acids addition to the freezing extender on the total antioxidant capacity (TAC), SOD, GSH activities and lipid peroxidation of the cryopresreved ram spermatozoa are presented in table 2. There was a non significant difference in TAC, SOD or GSH concentrations among the amino acids treated groups and the control. Whereas, the present data demonstrated that, in vitro provision of semen extender with $100 \mu \mathrm{l} / \mathrm{ml}$ non essential amino acids significantly $(\mathrm{P}<0.05)$ diminished lipid peroxidation of the frozen-thawed semen $(11.91 \pm 1.76 \mathrm{nmol} / \mathrm{ml})$ compared with the control semen $(20.11 \pm 2.68$ $\mathrm{nmol} / \mathrm{ml})$ and $200 \mu \mathrm{l} / \mathrm{ml}$ non essential amino acids $(23.56 \pm 2.60 \mathrm{nmol} / \mathrm{ml})$.

Table 2: Effect of non essential amino acids on antioxidant activities and lipid peroxidation of cryopresreved ram spermatozoa.

\begin{tabular}{lcccc}
\hline Different treatments & TAC & SOD & GSH & lipid peroxidation \\
\hline Control & $0.32 \pm 0.04 \mathrm{a}$ & $44.51 \pm 5.58 \mathrm{a}$ & $49.93 \pm 3.27 \mathrm{a}$ & $20.11 \pm 2.68 \mathrm{ab}$ \\
\hline NESS $20 \mu 1 / \mathrm{ml}$ & $0.32 \pm 0.03 \mathrm{a}$ & $47.92 \pm 2.07 \mathrm{a}$ & $50.83 \pm 4.94 \mathrm{a}$ & $19.85 \pm 2.2 \mathrm{ab}$ \\
\hline NESS $50 \mu 1 / \mathrm{ml}$ & $0.35 \pm 0.05 \mathrm{a}$ & $48.23 \pm 3.59 \mathrm{a}$ & $55.81 \pm 4.95 \mathrm{a}$ & $13.90 \pm 2.61 \mathrm{bc}$ \\
\hline NESS $100 \mu 1 / \mathrm{ml}$ & $0.38 \pm 0.04 \mathrm{a}$ & $52.18 \pm 6.69 \mathrm{a}$ & $63.85 \pm 6.69 \mathrm{a}$ & $11.91 \pm 1.76 \mathrm{c}$ \\
\hline NESS $200 \mu 1 / \mathrm{ml}$ & $0.29 \pm 0.04 \mathrm{a}$ & $42.89 \pm 1.76 \mathrm{a}$ & $50.56 \pm 3.47 \mathrm{a}$ & $23.56 \pm 2.60 \mathrm{a}$ \\
\hline
\end{tabular}

Values with different superscript letters in the same columns are significantly different at least $(\mathrm{P}<0.05)$.

NESS: non essential amino acids ; TAC: Total antioxidant capacity

SOD: Superoxide Dismutase ; GSH: Glutathione reductase enzyme

The effect of non essential amino acids addition to the freezing extender on the DNA integrity of the frozen-thawed ram spermatozoa are demonstrated in table 3 and fig (1). The present data indicated that, in vitro provision of semen extender with $100 \mu \mathrm{l} / \mathrm{ml}$ non essential amino acids significantly $(\mathrm{P}<0.05)$
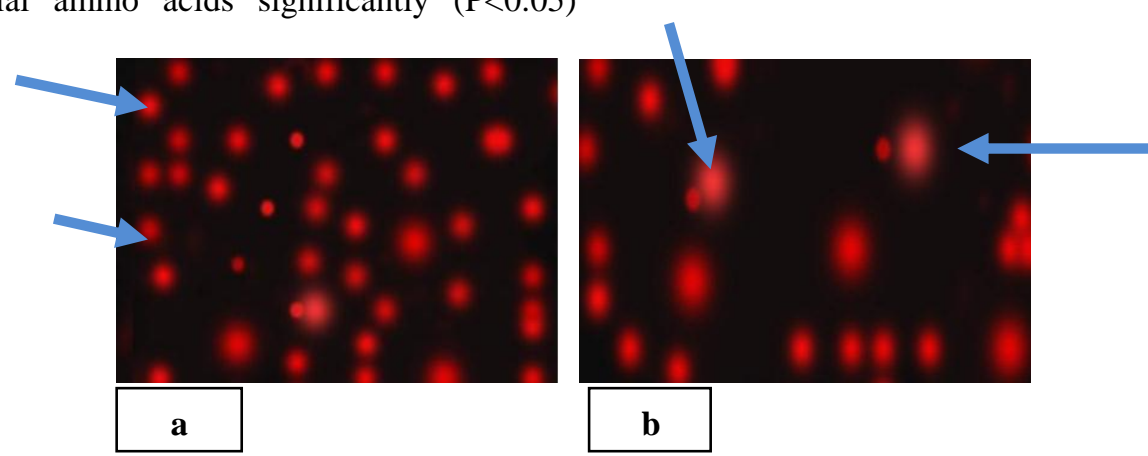

Fig (1): Epiflourescent images of ram spermatozoa after the single cell gel electrophoresis (comet) assay. a: Ram spermatozoa cryopresreved in $100 \mu \mathrm{l} / \mathrm{ml}$ non essential amino acids showed reduction in DNA fragmentation. b: Ram spermatozoa cryopresreved in control extender showed increased in DNA fragmentation as represented by an increasing amount of DNA present in the comet tail.

Table 3: Effect of non essential amino acids on DNA integrity of cryopresreved ram spermatozoa

\begin{tabular}{llll}
\hline \multicolumn{1}{c}{ Different treatments } & DNA integrity & Tail length & Tail moment \\
\hline Control & $6.83 \pm 1.82^{\mathrm{a}}$ & $4.05 \pm 0.57^{\mathrm{a}}$ & $25.71 \pm 3.47^{\mathrm{a}}$ \\
\hline $\mathrm{NESS} 20 \mu \mathrm{l} / \mathrm{ml}$ & $4.65 \pm 1.73^{\mathrm{ab}}$ & $3.21 \pm 0.16^{\mathrm{ab}}$ & $14.34 \pm 4.98^{\mathrm{ab}}$ \\
\hline $\mathrm{NESS} 50 \mu \mathrm{l} / \mathrm{ml}$ & $2.97 \pm 0.68^{\mathrm{ab}}$ & $3.25 \pm 0.30^{\mathrm{b}}$ & $9.59 \pm 1.98^{\mathrm{b}}$ \\
\hline NESS $100 \mu \mathrm{l} / \mathrm{ml}$ & $2.11 \pm 0.37^{\mathrm{b}}$ & $2.92 \pm 0.12^{\mathrm{b}}$ & $5.99 \pm 2.47^{\mathrm{b}}$ \\
\hline NESS $200 \mu \mathrm{l} / \mathrm{ml}$ & $6.59 \pm 1.28^{\mathrm{ab}}$ & $3.58 \pm 0.28^{\mathrm{a}}$ & $23.4 \pm 4.33^{\mathrm{a}}$ \\
\hline
\end{tabular}

Values with different superscript letters in the same columns are significantly different at least $(\mathrm{P}<0.05)$.

NESS: non essential amino acids 
Data concerning the effect of replenishing of semen extender with non essential amino acids on in vitro fertilizing potentials are presented in tables 4 . The current results revealed that, addition of $100 \mu \mathrm{l} / \mathrm{ml}$ non essential amino acids to the freezing extender had a positive effect $(\mathrm{P}<0.05)$ on the in vitro fertilization compared with the control semen. When $100 \mu \mathrm{l} / \mathrm{ml}$ non essential amino acids was added to the freezing extender, a higher proportion of in vitro fertilized oocytes $(51.21 \%$,$) compared with the$ control $((28.57 \%)$.

Table 4: Effect of non essential amino acids on in vitro fertilizing potentials of the cryopresreved ram semen.

\begin{tabular}{lccc}
\hline \multicolumn{1}{c}{ Treatments } & No. of oocytes & Penetration rate & Fertilization rate \\
\hline Control & 42 & $19(45.24) \mathrm{a}$ & $12(28.57) \mathrm{a}$ \\
\hline NESS $20 \mu \mathrm{l} / \mathrm{ml}$ & 46 & $27(58.69) \mathrm{a}$ & $16(34.78) \mathrm{a}$ \\
\hline NESS $50 \mu \mathrm{l} / \mathrm{ml}$ & 48 & $28(58.33) \mathrm{a}$ & $19(39.58) \mathrm{a}$ \\
\hline NESS $100 \mu \mathrm{l} / \mathrm{ml}$ & 41 & $26(63.41) \mathrm{a}$ & $21(51.21) \mathrm{b}$ \\
\hline NESS $200 \mu \mathrm{l} / \mathrm{ml}$ & 42 & $19(45.23) \mathrm{a}$ & $11(26.19) \mathrm{a}$ \\
\hline
\end{tabular}

Values with different superscript letters in the same columns are significantly different at least $\quad(\mathrm{P}<0.05)$.

NESS: non essential amino acids

Electron microscopic images of sagital sections of the frozen thawed sperm cells in control group showed, swollen plasma membrane segmentation of the outer acrosomal membrane and swollen acrosome (fig. 2). Moreover, control semen showed severe degeneration, marked vacuolation in the mitochondria with complete absence of the transverse cristae (fig. 3). Mean while, frozen thawed semen treated with $100 \mu \mathrm{l} / \mathrm{ml}$ NESS illustrated a well defined and intact plasma membrane, intact acrosomal membranes and homogenous mitochondria content and high-quality mitochondrial dense electron spaces with appeared transverse cristae (fig, 4, g, h \& i).

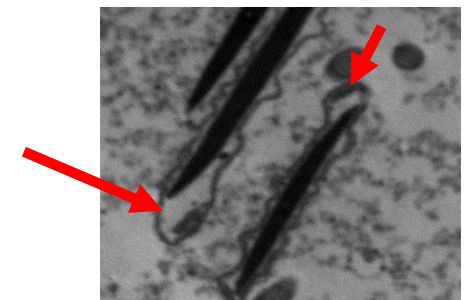

Fig2: (a)

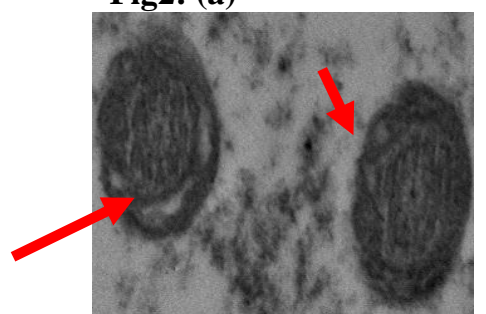

Fig 3: (d)

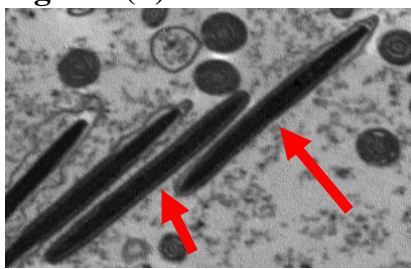

Fig:4 (g)

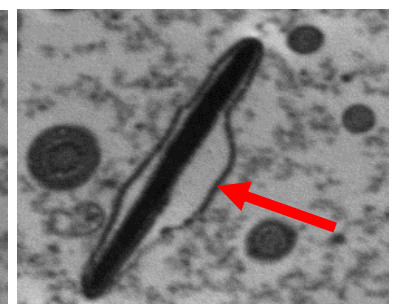

(b)

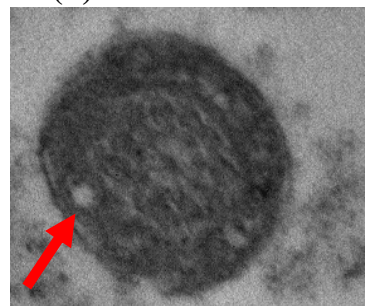

(e)

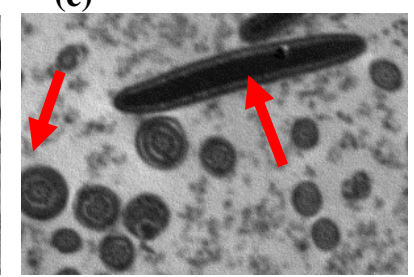

(h)

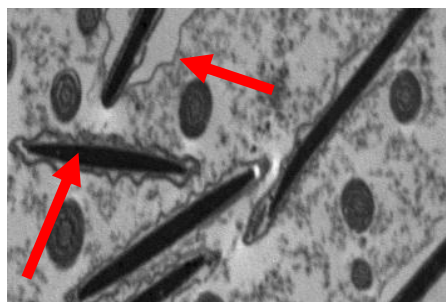

( c)

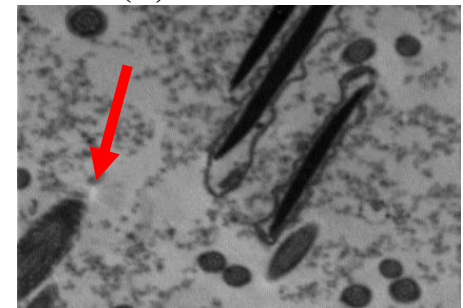

(f)

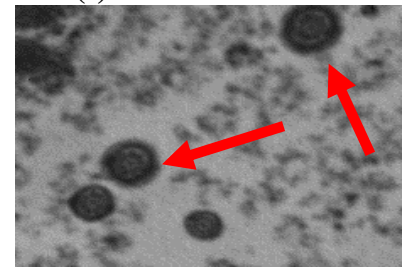

(i)

Fig. 2: (a, b \&c): Electron micrograph for a sagital section in the sperm head from a frozen-thawed semen sample of control group illustrating swollen, degenerated and vacuolated plasma membrane, segmentation of the outer acrosomal membrane and swollen acrosome (X 2500).

Fig. 3: (d, e \& f) Electron micrograph of a cross section in the neck region of sperm from frozen-thawed semen of control group showing severe degeneration (marked vacuolation) in the mitochondria that contained electron-translucent spaces with complete absence of the transverse cristae $(\times 12000)$.

Fig. 4: (g, h \& i): Electron micrograph for a sagital section in the sperm head from frozen-thawed semen sample treated with $100 \mu \mathrm{l} / \mathrm{ml}$ non essential amino acids illustrating intact plasma membrane (PM) and the nucleus content $(\mathrm{N})$ is homogenous in the electron density. Also, outer and inner acrosomal membranes are intact and the subacrosomal space is evident $(\times 2500)$. Also electron micrograph for a sagittal section in the sperm from a frozen-thawed semen sample illustrating intact outer acrosomal membrane $(\mathrm{OAM})$ inner acrosomal membrane $(\mathrm{IAM})$ in the electron density $(\times 2500)$ also illustrating good mitochondrial dense electron spaces with appeared transverse cristae $(\times 2500)$. 


\section{DISCUSSION}

The goal of cryopreservation is to obtain a high number of post-thawing survival normal sperms, but there are many factors during cryopreservation process, which can affect the post-thawing outcome (Azevedo, 2006). One of the most important factors appears to be extender constituents. The current results showed that cryopreservation led to changes in DNA, sperm cytoskeleton, inhibition of spermoocyte binding, and destruction of sperm axoneme, and consequently reduction of its mobility and fertilizing potentials. Supplementation of the freezing extender with non essential amino acids significantly augmented the characteristics of spermatozoa, such as motility, progressive motility, viability, acrosome and membrane integrity, antioxidant activity, in vitro fertilizing potentials and preserved the integrity of the fine structure of the spermatozoa against cryodamage during cryopreservation, in a dose dependent manner. These results are in line with the findings of of Uysal and Bucak (2007) and Bucak et al. (2008) for ram and Kundu et al. (2001), for goat sperm. The previous authors reported the positive effects of amino acids on motility and membrane integrity of the cryopresreved spermatozoa.

A variety of hypotheses and speculations have been proposed by various authors to explain the protective mechanism of amino acids during cryopreservation. However, the exact mechanism of sperm protection by amino acids has not been understood and remains obscure. Therefore, the present study is a trial to assess the entire mechanism of non essential amino acids on ram semen cryopreservation.

Kundu et al. (2001) suggested that the protective effects of amino acids may stem from their ability to form a layer on the spermatozoa surface, as these positively charged molecules can combine with the phosphate groups of sperm plasma membrane phospholipids. This may contribute to sperm osmolarity (Billard and Menezo, 1984) and this plays also a positive role in sperm vitality.

Moreover, amino acids have a stabilizing effect on cell membrane, (Lahnsteiner et al., 1992), limited membrane lesion and inhibited plasmolysis through membrane stabilization (Rudolph and Crowe, 1985). These findings are proved by the current electron microscope results that emphasized that the integrity of the cell plasma membrane, outer and inner acrosomal membranes integrity, mitochondrial dense electron spaces and the homogeneity of the nuclear content was preserved in the sperm cells cryopresreved with tris extender supplemented with non essential amino acids. Moreover, the present results revealed a beneficial effect of non essential amino acids on sperm mitochondrial membrane potential. Mitochondrial ATP synthesis is dependent on high mitochondrial membrane potential and an increase in this potential can result in improved mitochondrial function. This leads to amplify of ATP and subsequently augment of energy for spermatozoa and accounts for increased motility after the freezing/thawing processes (Martin et al., 2004).

Another theory for the beneficial effects of amino acids on the vital parameters of the cryopresreved spermatozoa may be attributed in fact to its antioxidant activities, scavenge ROS and protect sperm cell from toxic oxygen metabolites causing lipid peroxidation of sperm plasma membrane during cryopreservation (Alvarez and Storey, 1983 and Bilodeau et al., 2001). The current data confirmed this theory as non essential amino acids reduced lipid peroxidation of the cryopresreved spermatozoa compared with the control semen. Mammalian spermatozoa are susceptible to lipid peroxidation which destroys the structure of the lipid matrix of spermatozoa membrane, due to the attacks of ROS formed from reduction of oxygen, during cryopreservation. The damage of lipid matrix finally causes irreversible damage to the plasma membrane, membrane deterioration-due to membrane phase transitions, decreased sperm motility, loss in fertility and damage of the sperm DNA (Storey, 1997).

Because of the results of the current study that indicated the beneficial effect of non essential amino acids on diminishing the acrosomal damage, lipid peroxidation and enhancing the membrane integrity and their antioxidant activities during cryopreservation, it would ultimately enhance the fertilizing potentials of the cryopresreved spermatozoa.

Moreover, the results of the current study confirmed that increasing of the used amino acids to $200 \mu \mathrm{l} / \mathrm{ml}$ were detrimental to ram semen cryopreservation and decreased significantly the assessed characteristics of froze-thawed ram sperm. In agreement with this finding, Khlifaouia et al. (2005); Ali Al Ahmad et al. (2008) and El-Sheshtawy et al. (2008) reported that high concentrations of amino acids caused a significant reduction in sperm motility, membrane and acrosome integrity. The detrimental effects of amino acids in extender increased when the concentration of used amino acids rides and the reason for these negative effects is the increased osmotic pressure and hyper tonicity.

In conclusion, results emerging from this study clearly demonstrated that supplementation of semen extender with non essential amino acids exerted valuable effects on the quality and the in vitro fertilizing potentials of the frozen-thaw ram spermatozoa in a dose dependent manner and 
$100 \mu \mathrm{l} / \mathrm{ml}$ appeared to be the best concentration. These constructive effects appeared due to improvement of the antioxidant activities, diminishing of the lipid peroxidation of the cryopresreved and preserving the functional integrity of the plasma membrane and mitochondrial function of the cryopresreved spermatozoa.

\section{REFERENCES}

Aitken, R.J. (2000): Possible redox regulation of sperm motility activation. J. Androl. 21 (4): 491-496.

Ali Al Ahmad, M.Z.; Chatagnon, G.; Amirat-Briand, L.; Moussa, M.; Tainturier, D.; Anton, M. and Fieni, F. (2008): Use of glutamine and low density lipoproteins isolated from egg yolk to improve buck semen freezing. Reprod. Domest. Anim. 43:429-436.

Alvarez, J.G. and Storey, B.T. (1983): Taurine, hypotaurine, epinephrine and albumin inhibit lipid peroxidation in rabbit spermatozoa and protect against loss of motility, Biol. Reprod., 29: 548-555.

Atessahin, A.; Bucak, M.N.; Tuncer, P.B. and Kizil, M. (2008): Effect of antioxidant additives on microscopic and oxidative parameters of Angora goat semen following the freezethawing process. Small Rumin. Res. 77: $38-44$.

Azevedo, H.C. (2006): Spermatic integrity and function in RAM cryopreserved sêmen after incorporation of cholesterol, desmosterol, oleic-linoleic acid and -lactalbumin. Thesis (Doctor in Veterinary Medicine). Faculty of Veterinary Medicine and Animal Science, UNESP, Botucatu

Betteridge, D.J. (2000): What is oxidative stress? Metabolism, 49: 3-8.

Billard, R. and Menezo, Y. (1984): The amino acids alanine on Rain-bow trout seminal fluid and blood plasma: a comparison with carp. Aquaculture, Cryobiology, 46: 17-25.

Bilodeau, J.F.; Blanchette, S.; Gagnon, C. and Sirard, M.A. (2001): Thiols prevent H O mediated loss of sperm motility in cryopresreved bull semen. Theriogenology, 56: 275-286.

Boe-Hansen, G.B. (2005): Hydrogen peroxide alters the physical state and function of the plasma membrane of pulmonary artery endothelial cells. J. Cell Phys., 20: 362-374.

Boonkusol, D.; Saikhun, K. and Ratanaphumma, P. (2010): Effect of extender and storage time on motility and ultrastructure of cooledpreserved boar spermatozoa. Kasetsart J. Nat. Sci., 44: 582-589.

Bucak, M.N.; Atessahin, A. and Yuce, A. (2008): Effect of antioxidants and oxidative stress parameters on ram semen after the freeze- thawing process. Small Rum. Res. 75: 128-134.

Budai, C.; Egerszegi, I.; Olah, J.; Javor, A. and Kovacs, A. (2014): The Protective Effect of Antioxidants on Liquid and Frozen Stored Ram Semen. Review. Animal Science and Biotechnologies, 47 (1): 46-52.

Camara, D.R.; Silva, S.V.; Almeida, F.C.; Nunes, J.F. and Guerra, M.M.P. (2011): Effects of antioxidants and duration of pre-freezing equilibration on frozen thawed ram semen. Theriogenology, 76: 342-350.

Chu, T.M.; Aspinall, D. and Paleg, L.G. (1974): Stress metabolism: Part 6. Temperature stress and the accumulation of proline in barley and radish. Aust. J. Plant Physiol. 1:87-97.

Costat Computer Program Copyright (1986): Version 3.03 copyright Cottort Software.

Cortassa, S.; Aon, M.A.; Winslow, R.L. and O'Rourke, B. (2004): A mitochondrial oscillator dependent on reactive oxygen species. Biopysic. J., 87: 2060- 2073.

El-Sheshtawy, R.I.; El-Sisy, G.A. and El-Nattat, W.S. (2008): Use of selected amino acids to improves buffalo bull semen cryopreservation. Global Vetrinaria, 2: 146-150.

Esmaeili, V.; Shahverdi, A.; Alizadeh, A.R.; Alipour, H.; Towhidi, A. and Zarrabi, M. (2012): Fatty acid profiles of ram's sperm after removing some fatty acid sources from the diets and persistency of fatty acids in sperm, Int. J. Fert. Steril., 5: 211-216.

Flohe, L. and Otting, F. (1984): Superoxide dismutase assays. Methods Enzymol., 105: 93-104.

Giulini, S.; Sblendorio, V.; Xella, S.; La Marca, A.; Palmieri, B. and Volpe, A. (2009): Seminal plasma total antioxidant capacity and semen parameters in patients with varicocele. Reproduction Biology Online, 18: 617-621 29.

Hughes, C.M.; Lewis, S.E.M.; McKelvey-Martin, V.J. and Thompson, W. (1996): A comparison of baseline and induced DNA damage in human spermatozoa from fertile and infertile men, using a modified comet assay. Mol. Hum. Reprod., 2: 613-619.

Khlifaouia, M.; Battuta, I.; Bruyasa, J.F.; Chatagnona, G.; Trimecheb, A. and Tainturiera, D. (2005): Effects of glutamine on post-thaw motility of stallion spermatozoa: an approach of the mechanism of action at spermatozoa level. Theriogenology 63: 138149.

Kundu, C.N.; Das, K. and Majumder, G.C. (2001): Effect of amino acids on cauda epididymal sperm cryopreservation using a chemically defined model system. Cryobiology, 41: 21-27. 
Lahnsteiner, F.; Weismann, T. and Patzner, R.A. (1992): Fine structural changes in spermatozoa of the grayling, Thymallus thymallus (Pisces:Teleostei), during routine cryopreservation. Aquaculture 103: 73-84.

Leoni, G.G.; Succu, S.; Berlinguer, F.; Rosati, I.; Bebbere, D.; Bogliolo, L.; Ledda, S. and Naitana, S. (2006): Delay on in in vitro kynetic development of prepubertal ovine embryos. Anim. Reprod. Sci. 92: 373-383.

Maia, M.S.; Bicudo, S.D.; Azevedo, H.C.; Sicherle, C.C.; Souza, D.B. and Rodello, L. (2009): Motility and viability of ram sperm cryopreserved in a Tris-egg yolk extender supplemented with anti-oxidants. Small Rumin. Res. 85 (2-3): 85-90.

Martin, G.; Sabido, O.; Durand, P. and Levy, R. (2004): Cryopreservation induces an apoptosis-like mechanism in bull sperm. Biol. Reprod., 71: 28-37.

Parrish, J.J.; Susko-Parrish, J.; Winer, M.A. and First, N.L. (1988): Capacitation of bovine sperm by heparin. Biol. Reprod., 38: 1171-1180.

Peris, S.I.; Bilodeau, J.F. and Dufour, M. (2007): Impact of Cryopreservation and reactive oxygen species on DNA inetgrity, lipid peroxidation, and functional parameters in ram sperm. Mol. Reprod. Dev. 74: 878-892.

Placer, Z.A.; Cushman, L.L. and Johnson, B.C. (1966): Estimation of product of lipid peroxidation (malonyl dialdehyde) in biochemical systems. Anal. Biochem., 16: 359-364.

Rudolph, A.S. and Crowe, J.H. (1985): Membraned stabilization during freezing: the role of two natural cryoprotectants, trehalose and proline. Cryobiology 22: 367-377.

Salamon, S. and Maxwell, W.M.C. (2000): Storage of ram semen, Animal Reproduction Science, $62,77-111$.

Sedlak, J. and Lindsay, R.H.C. (1968): Estimation of total, protein-bound and nonprotein sulfhydryl groups in tissue with Ellman's reagent. Anal. Biochem., 25: 192-205.

Sicherlea, C.C.; Maia, M.S.; Bicudoa, S.D.; Rodelloa, L. and Azevedoc, H.C. (2011): Lipid peroxidation and generation of hydrogen peroxide in frozen-thawed ram semen supplemented with catalase or Trolox C.C. Small Ruminant Research 95: 144-149.

Storey, B.T. (1997): Biochemistry of the induction and prevention of lipoperoxidative damage in human spermatozoa, Molecular Hum. Reprod., 3 (3): 203-213.

Uysal, O. and Bucak, M.N. (2007): Effects of oxidized glutathione, bovine serum albumin, cysteine and lycopene on the quality of frozen-thawed ram semen. Acta Vet. Brno 76: 383-390.

\section{تأثثر الاحماض الامينية علي قابلية تجميد حيامن الكباش والتغيرات الكميائية والتراكيب الدقيقة

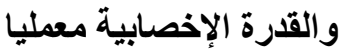 \\ مجلي رمضان بلر ، زاهر محمد رواش ، غادة حسن عبل الرحمن ، محمد محمد عاصي ، هاني محمد حسن}

Email: magdybadr69@yahoo.com

Assiut University web-site: www.aun.edu.eg

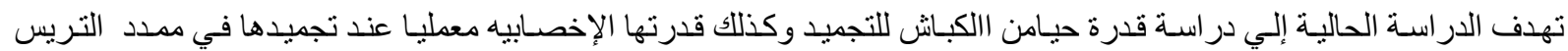

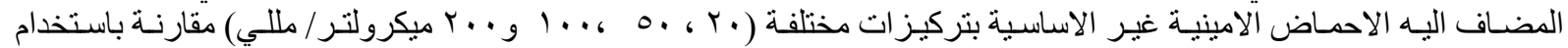

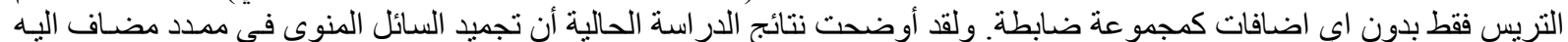

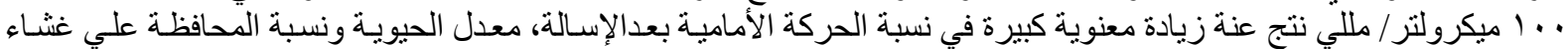

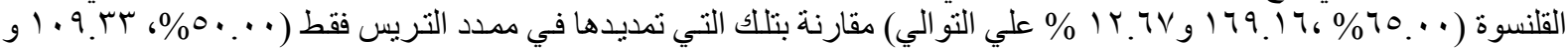

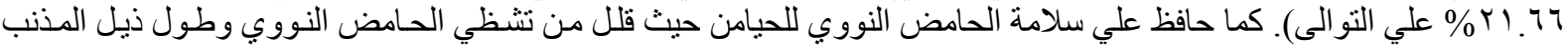

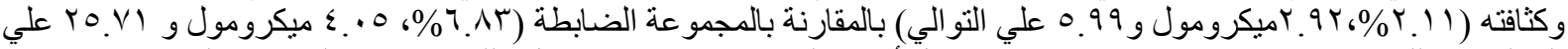

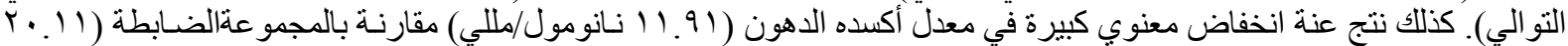

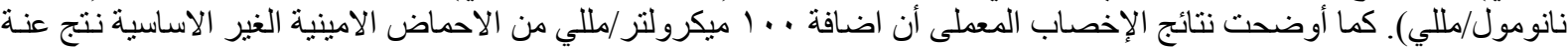

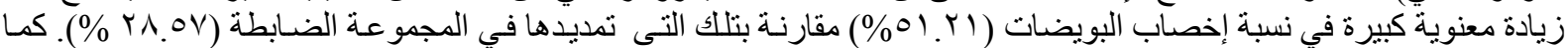

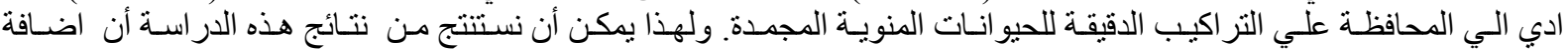

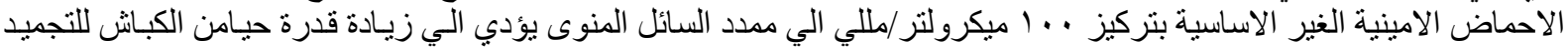

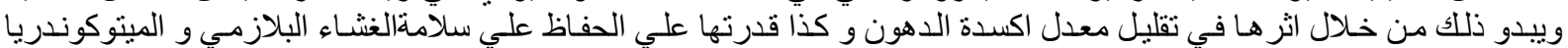
للحيو انات المنوية المجمدة. 